\title{
Identification of plant growth promoting Rhizosphere Bacillus sp. WG4 antagonistic to Pythium myriotylum and its enhanced antifungal effect in association with Trichoderma
}

\author{
J.C. Jimtha. J.C ${ }^{1}$, P. Jishma ${ }^{1}$, G.B. Arathy ${ }^{1}$, C.Anisha ${ }^{1}$, E.K. Radhakrishnan ${ }^{1 *}$ \\ ${ }^{1}$ School of Biosciences, Mahatma Gandhi University, Priyadharshini Hills PO, Kottayam Dist, Kerala, India, \\ Pin 686560.Corresponding author: radhakrishnanek@mgu.ac
}

\begin{abstract}
Among the various rhizospheric bacterial isolates screened from Westren Ghat regions of Kerala, a Bacillus sp. with both antagonistic activity to Pythium myriotylum and plant growth promoting properties was identified. Scanning electron microscopic analysis revealed significant ultrastructural changes of hyphae and spores of $P$. myriotylum upon treatment with Bacillus sp.WG4. For the structural characterization of antagonistic compound in the crude exract, GC MS analysis was carried out and this has resulted in the identification of presence of pyrrolo [1,2- a] pyrazine-1,4-dione, hexahydro-3-(phenylmethyl) as basis of antifungal activity. The in vivo antifungal activity of Bacillus strain was analysed by pre-inoculation of this to ginger rhizome. Here the presence of Bacillus strain was found to provide effective protection to ginger rhizome upon inoculation with Pythium myriotylum. Very interestingly, when the Bacillus strain was checked for its synergistic antifungal activity with commercially available biocontrol agent Trichoderma, the combination was found to have increased antifungal activity. Due to its antifungal and growth enhancement effects, the isolated strain can be of promising application as antifungal plant probiotic agent alone or in combination with other agents like Trichoderma.
\end{abstract}

Keywords: Bacillus sp., WG4, biocontrol, rhizosphere, plant growth promoting activity, Pythium myriotylum.

\section{Introduction}

Although several bacterial species are known for their antifungal activity, Bacillus sp., are highly impressive due to their endospore formation (Schaeffer 1969), extreme tolerance to heat and desiccation (Handelsman et al., 1990) and also due to their potential to produce a wide range of antibiotics (Katz and Demain 1977), toxins, hydrolases and lipopeptides (Lamsal et al., 2012). They have also been iden- tified to have a wide range of distribution as soil-inhabiting, epiphytic, endophytic (Mora et al., 2014) or rhizosphere organisms and due to this they have been reported as highly efficient biocontrol agents for seed treatment applications (Soylu et al., 2005). Their safety and ability to produce compounds beneficial for agronomical purpose makes Bacillus sp. a highly studied organism (Earl et al., 2008). 
Phytopathogenic fungi including oomycetes are of global concern to food security, as they are difficult to control due to their genetic plasticity and population variability. In addition to this, they can have severe economic impact as in the case of crops like ginger, where the biotic stress due to $P$. myriotylum causes significant reduction in yield and thereby annual export. Evolution of pesticide resistant pathogens, environmental toxicity of pesticides and the difficulty in identifying disease resistant plant varieties makes the common procedures ineffective on a large scale. All these make it highly demanding to investigate rhizobacteria from various environments for plant protective properties to explore its agricultural applications. Fungal biological control agents like Trichoderma are among the most successful tools applied against plant pathogenic fungi, especially oomycetes. They are also reported to play an important role in sustainable agriculture because of its additional role in increase of plant growth and yield (Seidl et al., 2005). So identifying promising rhizobacteria will pave the way to enhance the effect of these organisms by forming microbial consortia.

Current study was targetted towards identification of Bacillus sp. with strong activity to inhibit the growth of P.myriotylum. Bacillus sp. which was isolated and screened for antifungal properties was characterized by 16S rDNA sequence analysis. The isolated organism was found to have property to alter fungal morphology as confirmed by SEM analysis. Its enhanced activity in association with Trichoderma and the presence of additional plant growth enhancement features provide opportunities to develop compatible biocontrol formulations to explore its field applications.

\section{Materials and Methods}

\subsection{In vitro antagonistic studies}

Among the various rhizobacteria screened from Western Ghat regions, one isolate from Curculigo orchioides was found to have in vitro antagonistic activity towards Pythium myriotylum. For in vitro antagonistic studies, the rhizobacteria was streaked on the edge of the PDA in a petridish, and a mycelial plug (6 $\mathrm{mm}$ diameter) of the pathogen was inoculated at the centre. Growth inhibition was evaluated by analysing the inhibition zones from the bacterial colony to the edge of the spreading fungal mycelium after incubation for 5 days at 25 ${ }^{\circ} \mathrm{C}$ as per previously described methods (Chen et al., 2008). For optimal production of the antifungal compound, the selected organism was cultured in various media like Nutrient broth, Sabouraud's dextrose broth, Potato Dextrose broth, Sucrose broth and Solid Rice media. For this the organism was incubated in $30 \mathrm{~mL}$ seed medium for $12 \mathrm{~h}$ with $200 \mathrm{rpm}$, and from this $10 \%$ inoculum was added to $100 \mathrm{~mL}$ fermentation medium followed by incubation at $30{ }^{\circ} \mathrm{C}$ for 10 days. The culture supernatant was extracted with ethyl acetate and the extract was concentrated in a rotary vaccum evaporator.

\subsection{Extraction of culture supernatants}

Extracts were prepared from 3L culture of cell free supernatant with ethyl acetate followed by evaporation to dryness. The residue was dissolved in methanol and agar well diffusion assay was used for determination of antagonistic activity of the extract. For this, mycelial mat (5 $\mathrm{mm}$ in diameter) of Pythium myriotylum was placed at the center of the plate containing PDA medium and a well of $5 \mathrm{~mm}$ diameter was made on the agar with a sterile steel borer at the edge of the plate and $60 \mu \mathrm{L}$ of the extract was poured into the well followed by incubation for $72 \mathrm{hr}$ at $27^{\circ} \mathrm{C}$.

\subsection{Screening of rhizosphere bacteria for plant growth promoting properties}

The selected isolate was screened for 1-Aminocyclopropane-1-carboxylate (ACC) deaminase activity by 
using DF minimal media. For indole-3-acetic acid (IAA) production analysis, the bacteria was cultured in nutrient broth with $0.2 \%$ tryptophan and IAA was analysed by Salkowski method. Phosphate (P) solubilization assay was carried out by inoculating on Pikovskaya medium and siderophore production was analysed using modified blue agar CAS medium containing chrome azurol S (CAS) and hexa decyl trimethyl ammonium bromide (HDTMA) as indicators (Jasim et al., 2013). Ammonia production was determined as described by (Ahmad et al., 2008) and $\mathrm{HCN}$ production was analysed as described by (Chakraborty et al., 2009) and nitrogen fixation was checked on Jensen's media (Jimtha et al., 2014).

\subsection{Identification of the bacterial isolate}

Identification of the selected bacterial isolate was done by biochemical and 16S rDNA based sequencing based method. Genomic DNA was isolated from the bacterial isolate and was used as template for PCR. Primers used for the amplification of part of 16S rDNA were 16SF (50-AgA gTTTgA TCM Tgg CTC-30) and 16SR (50-AAg gAg gTg WTCCAR CC-30) and were selected based on the previous reports of Chun and Goodfellow (Chun and Goodfellow 1995)t>580@;.PCR was carried out in a $50 \mu$ L reaction volume containing $50 \mathrm{ng}$ of genomic DNA, $20 \mathrm{pmol}$ of each primer, 1.25 units of Taq DNA polymerase (Bangalore Genei), $200 \mu \mathrm{M}$ of each dNTPs and 1X PCR buffer. PCR was carried out for 35 cycles in a MycyclerTM (Bio-Rad, USA) with the initial denaturation at $94{ }^{\circ} \mathrm{C}$ for $3 \mathrm{~min}$, cyclic denaturation at 94 ${ }^{\circ} \mathrm{C}$ for $30 \mathrm{~s}$, annealing at $58^{\circ} \mathrm{C}$ for $30 \mathrm{~s}$ and extension at $72{ }^{\circ} \mathrm{C}$ for 2 min with a final extension of $7 \mathrm{~min}$ at $72{ }^{\circ} \mathrm{C}$. The PCR product was checked by agarose gel electrophoresis, purified and was further subjected to sequencing in Scigenome, Ernakulam, Kerala, India. The sequence data was checked by BLAST analysis
(Zhang et al., 2000). The phylogenetic analysis of the 16SrDNA sequences of the isolates obtained in the study was conducted with MEGA 5 using neighbor-joining method with 1,000 bootstrap replicates (Tamura et al., 2011).

\subsection{Morphological changes of Pythium myriotylum induced by the selected rhizobacteria}

For the detection of morphological and ultra structural changes of Pythium myriotylum due to the effect of the bacterial isolate, dual culture method was used as explained above. Both the Light Microscopy (Chaurasia et al., 2005) and SEM analysis were carried out for Pythium myriotylum from the dual culture plate along with Pythium myriotylum alone from PDA as control. Sample preparation and SEM observation were done as described by previous methods (Furlaneto et al., 2012). Hyphal samples of Pythium myriotylum were excised and were fixed in $2.5 \%$ glutaraldehyde at $4{ }^{\circ} \mathrm{C}$ for $2 \mathrm{~h}$, washed in phosphate buffered saline (PBS) for 4 times (15 min each), dehydrated in a graded ethanol series $(30 \%, 50 \%, 70 \%, 80 \%, 90 \%$, and $100 \%)(10$ min each) air dried and viewed under SEM.

\subsection{Enhanced antiungal effect of selected isolate in association with Trichoderma}

The selected bacterial isolate and commercially available Trichoderma strains were analysed for their combined activity against Pythium myriotylum. For this, the extracts of these strains were made using the same methodology described above. Then the effect of individual applications $(60 \mu \mathrm{L})$ and the combined applications $(30 \mu \mathrm{L}$ each) of extract were evaluated by well diffusion method with incubation at $24{ }^{\circ} \mathrm{C}$ in dark for 4 days. The Pythium myriotylum which was simultaneously grown was used as control (RuanoRosa et al., 2013). 


\subsection{GC-MS analysis of crude cell extract}

Identification of the antimicrobial metabolites was done by Gas Chromatography-Mass Spectrometry (GC-MS) analysis with Agilent Technologies-7890 GC System, $5975 \mathrm{C}$ inert MSD. $1 \mu \mathrm{L}$ of sample solution was injected into the $\mathrm{GC}$ system provided with 30 m X $250 \mu \mathrm{m}$ X $0.25 \mu \mathrm{m}$ Agilent 190913-433 column at $325{ }^{\circ} \mathrm{C}$ and Helium was used as a carrier gas at a flow rate of $1.1 \mathrm{~mL} / \mathrm{min}$. For GC-MS the GC oven was held at $100{ }^{\circ} \mathrm{C}$ and then ramped from $100{ }^{\circ} \mathrm{C}$ to $250{ }^{\circ} \mathrm{C}$ at $5{ }^{\circ} \mathrm{C} / \mathrm{min}$. The chromatogram and mass spectra were recorded and analyzed. The $\mathrm{m} / \mathrm{z}$ peaks representing mass to charge ratio characteristic of the antimicrobial fractions were compared with those in the mass spectrum of NIST (National Institute for Standards and Technology) library of the corresponding organic compound.

\subsection{Control of Pythium myriotylum infection on} Ginger rhizome using Bacillus sp.

To analyze the effect of Bacillus sp. on ginger rhizome, surface sterilized ginger was treated with sterile nutrient broth (T1), distilled water (T2) and overnight culture of Bacillus sp. (T3). Each set contained three pieces of the ginger taken in a petri dish which was soaked in T1, T2 and T3 for 30 minutes and inoculated with P. myriotylum. These rhizomes were observed for $P y$ thium myriotylum infection for 7 days.

\section{Results}

3.1. Isolation and characterization of potential bacterial antagonists

Among the various rhizosphere isolates purified from Western Ghat, the isolate from Curculigo orchioides produced prominent zone of inhibition against Pythium myriotylum (Figure 1).

The zones of inhibition against Pythium myriotylum were particularly well developed with about $44 \%$ inhibition. Extracts prepared from $3 \mathrm{~L}$ of nutrient broth culture was used to check the antifungal activity. Among the five media used, extract from nutrient broth showed excellent growth inhibition towards Pythium myriotylum.

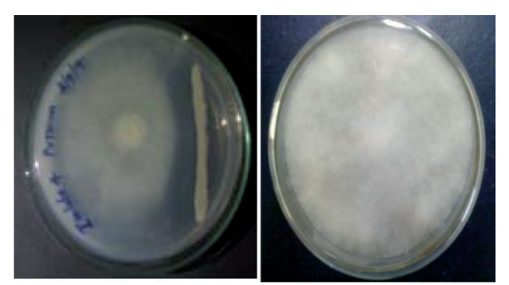

(a)

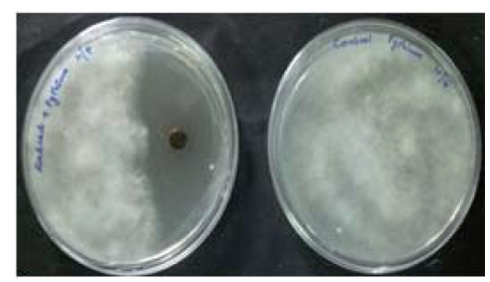

(b)

Figure 1. Antagonistic effect of Bacillus sp. WG4 against Pythium myriotylum along with its control, (a) Dual culture assay, (b) activity of crude extract. 
3.2. Identification of the Bacterial Isolate and Screening of multiple plant growth promoting potentials

Plant growth promoting properties like Indole acetic acid, ACC Deaminase, Phosphate solubilization and $\mathrm{HCN}$ were found to be positive for the selected isolate (Figure 2). The selected isolate was identified biochemically and by molecular analysis (Figure 3) as Bacillus sp. and it showed $99 \%$ identity with Bacillus cereus in BLAST analysis (Figure 4). The sequences were deposited to NCBI (1913842).

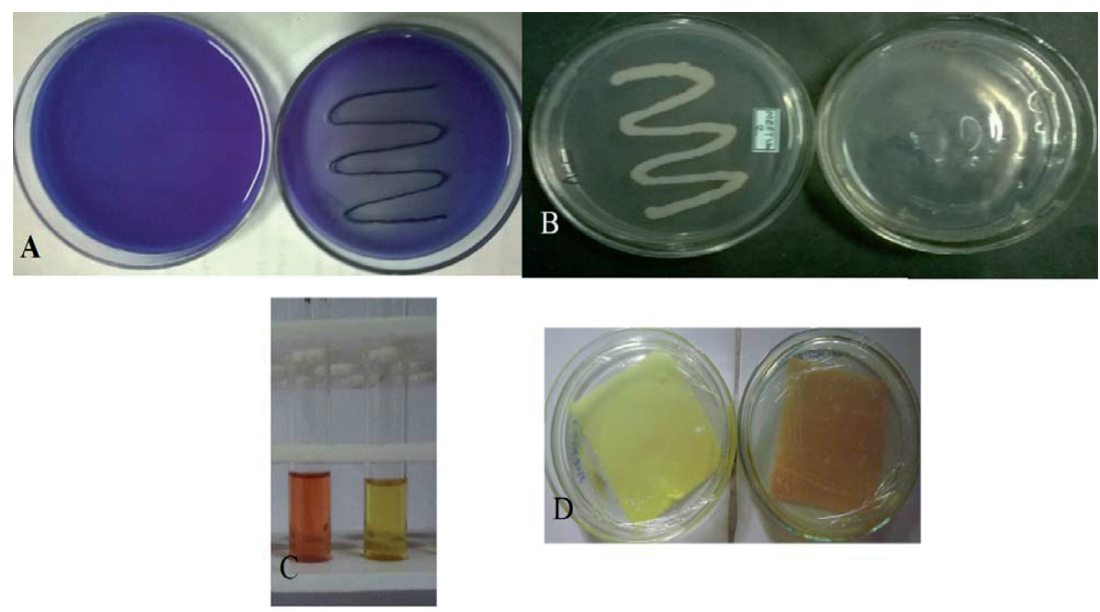

Figure 2. Plant growth promoting properties exhibited by the selected isolate. A: Phosphate solubilization, B: ACC Deaminase production, C: IAA production, D: HCN production along with its uninoculated control.

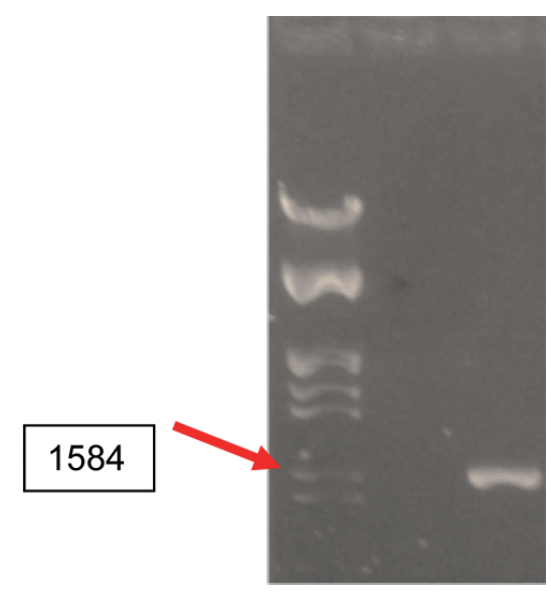

Figure 3. PCR amplification of 16S rDNA-(Lane 1)- Lambda DNA/EcoR1/Hind III Double digest marker (Lane 2)- Negative Control, (Lane 3) Rhizosphere isolate. 
3.3. Effect of crude extract on mycelium growth of Pythium myriotylum

Dual culture showed inhibitory effect of isolated organism on growth and morphology of P.myriotylum as it could not extend as normal and were distorted and granulated, whereas the mycelia from the control sample were normal and healthy. A crescent inhibition line was formed around the extract containing sample (Figure 5), while the mycelia close to the control sample covered the well. Disintegration of mycelia and hyphae, lysis of hyphae and suppression of formation of new oogonia were also observed in light and scanning electron microscopic images.

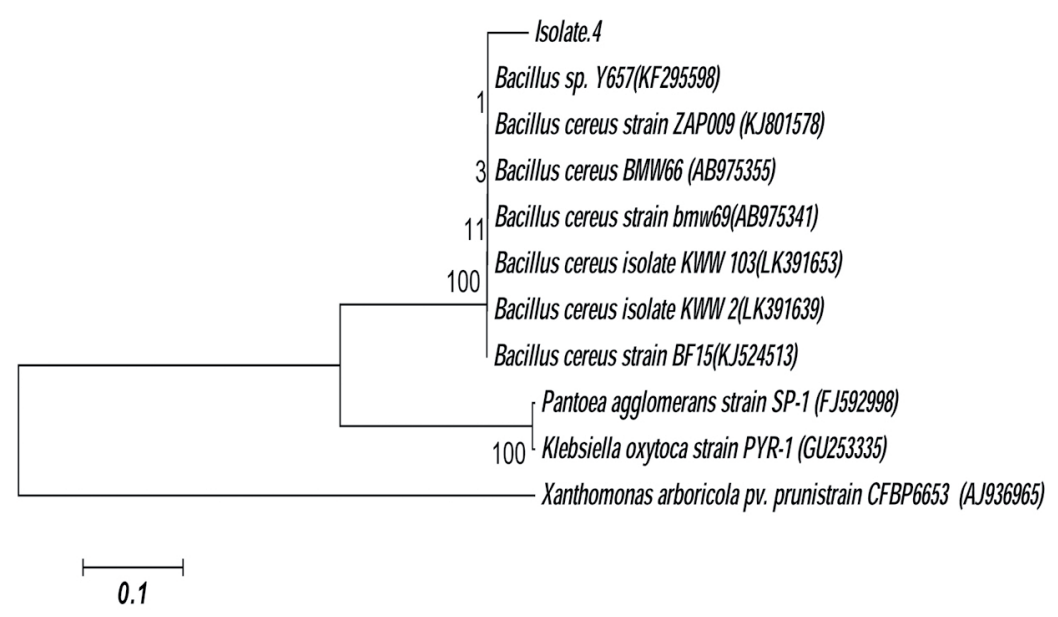

Figure 4 Phylogenetic tree showing the relationship of the isolate to closely related bacteria. The tree was obtained using the neighbour-joining method. The numbers at branching points refer to bootstrap values, based on 1000 replicates.

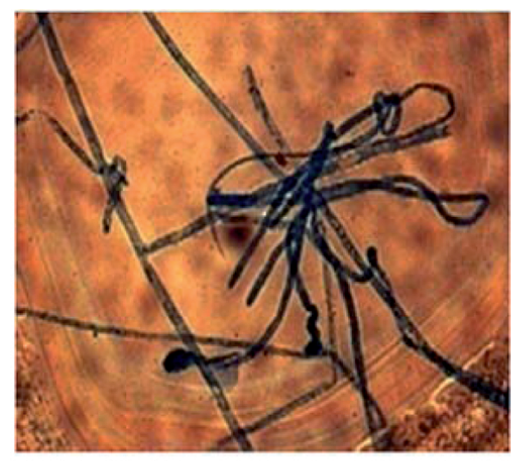

(a)

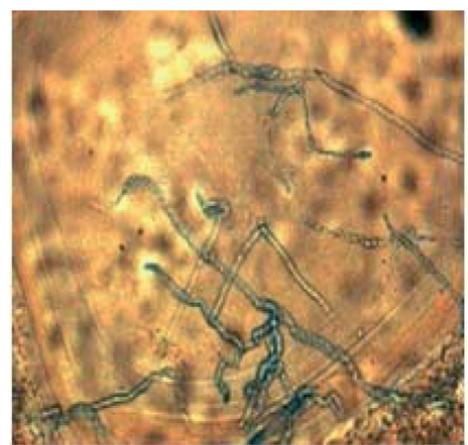

(b)

Figure 5.1. Light Microscopic images of Pythium myriotylum mycelia showing morphological distortion in dual culture. (a) Normal mycelial morphology of Pythium myriotylum; (b) Altered mycelial morphology of Pythium myriotylum in presence of antagonistic Bacillus sp. WG4. 


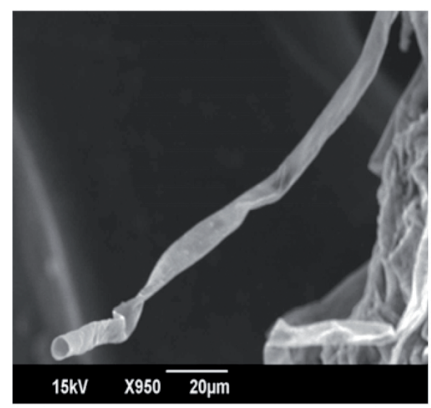

(a)

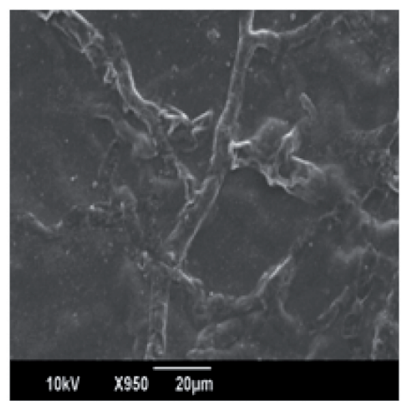

(b)

Figure 5.2. Scanning Electon Microscopic images of Pythium myriotylum mycelia showing morphological distortion in dual culture

(a) Normal mycelial morphology of Pythium myriotylum; (b) Altered mycelial morphology of Pythium myriotylum in presence of antagonistic Bacillus sp. WG4

\subsection{Effect of bacterial and Trichoderma extract on} Pythium myriotylum growth

A morphological interaction such as contact inhibition has already been reported between Pythium myriotylum and commercial biocontrol agent Tricho- derma. Interestingly, the Bacillus extract significantly reduced the in vitro growth of Pythium myriotylum alone as well as in association with Trichoderma extract. But the combination, significantly reduced $P y$ thium myriotylum growth relative to their independent effect due to synergistic action (Figure 6).

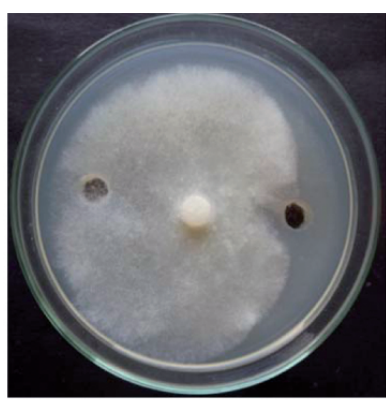

(a)

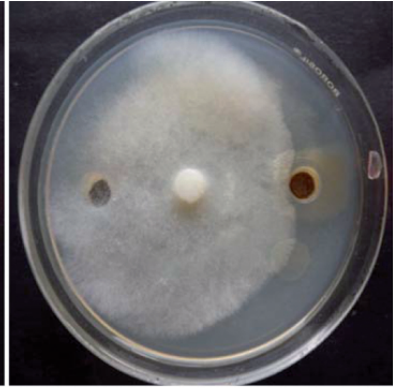

(b)

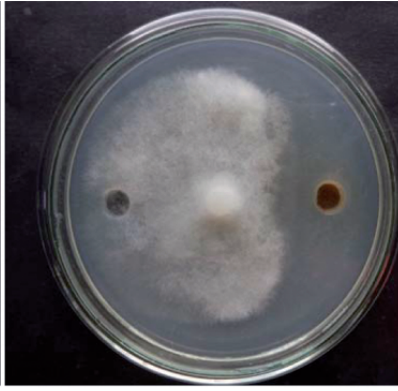

(c)

Figure 6. Antiungal activity of crude extracts on the radial growth of Pythium myriotylum

(a) Effect of crude extract of Trichoderma sp., (b) Effect of crude extract of Bacillus sp. WG4

(c) combined effect of Trichoderma and Bacillus sp. WG4 extracts. 


\subsection{GC-MS analysis of crude cell extract}

dione, hexahydro-3-(phenylmethyl) with a molecular

GC-MS analysis of crude extract of Bacillus sp. reweight of 244.2 at a retention time of $30.358 \mathrm{~min}$ with vealed the presence of pyrrolo [1,2- a] pyrazine-1,4$98 \%$ similarity with NIST library data (Figure 7 ).

(a)

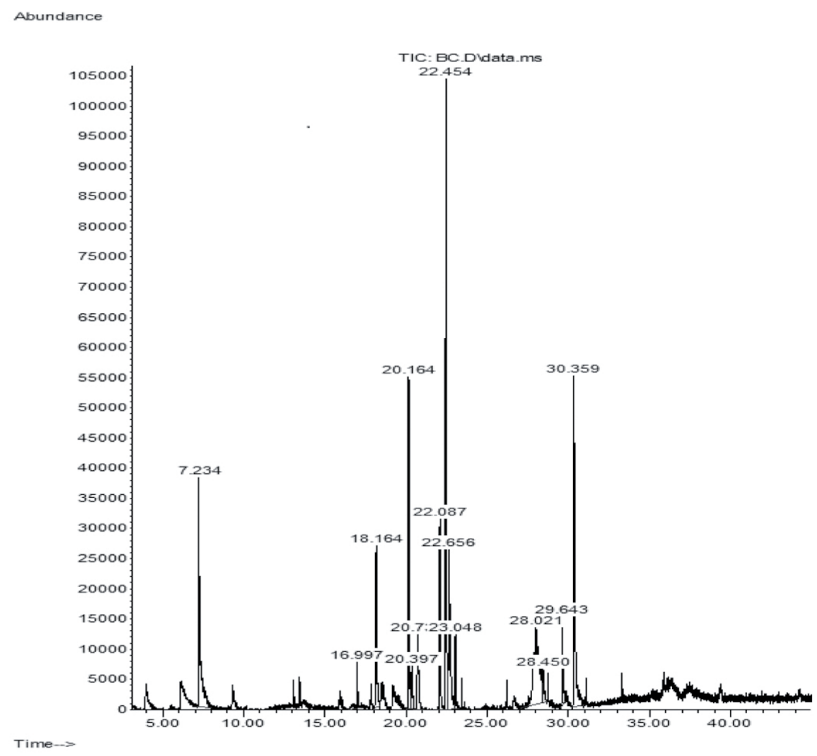

Abundance

(b)

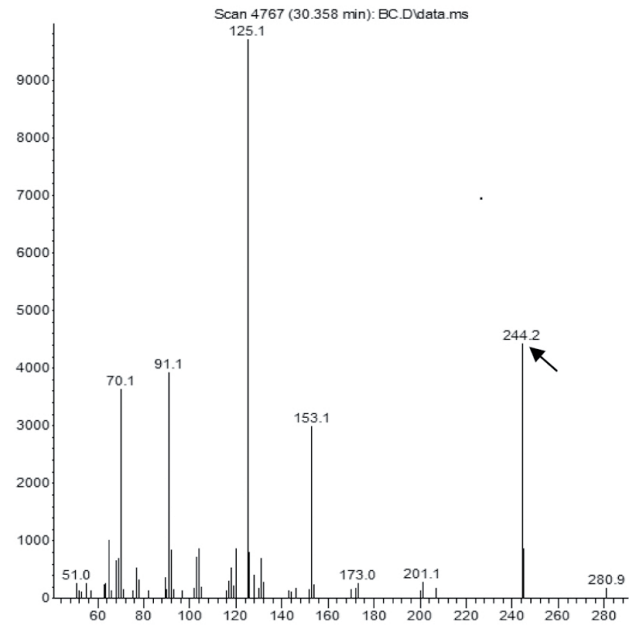

Figure 7. GC-MS (a) chromatogram and (b) spectrum of pyrrolo [1, 2-a] pyrazine-1,4-dione, hexahydro-3(phenylmethyl) present in the crude extract of Bacillus sp. WG4 


\subsection{In vivo rhizome protective effect of Bacillus sp. on ginger rhizome}

The Bacillus sp. was pre-inoculated on to ginger rhizome which was further challenged with Pythium myriotylum to study the inhibitory effect of the bacteria on colonization by fungal pathogen. Very inter- estingly, after $96 \mathrm{~h}$ of incubation only those rhizome pieces which had been pre-treated with nutrient broth as control showed the presence of mycelial growth of Pythium myriotylum. At the same time, the rhizome pieces which had been pre-incubated with Bacillus sp. culture were found to have inhibition of growth of $P y$ thium myriotylum even after $96 \mathrm{~h}$. (Figure 8).

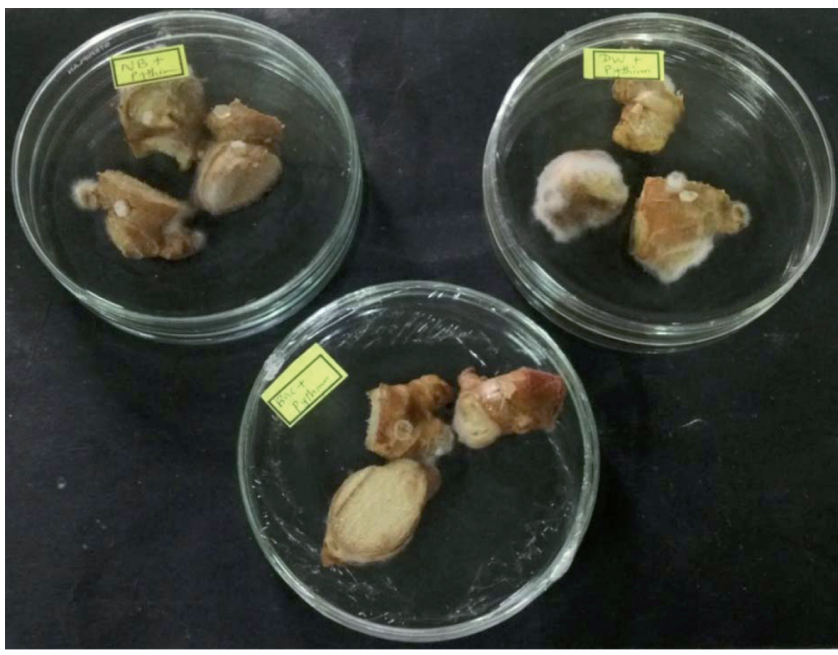

Figure 8. Rhizome inoculation study showing the difference in the infection of Pythium myriotylum when inoculated on rhizome pretreated with Bacillus sp. WG4 (T1-Nutrient broth control, T2-Distilled water control, T3-Bacillus sp.WG4 treated sample).

\section{Discussion}

Beneficial microorganisms are highly promising for more rational and safe crop management practices. Bacillus sp., are important biocontrol agents (Lee and Kim 2016) with potential antifungal activity against a number of plant pathogens (Zaccardelli et al., 2013). In addition to this they also have been reported to have remarkable impact on host plant by increasing the availability of nitrogen and phosphorous and thereby causing nutrient unavailability to phytopathogens (Malviya et al.,
2012). The first commercially available biopesticides prepared from strains of B. subtilis, branded as Quantum ${ }^{\circledR}, \operatorname{Kodiak}^{\circledR}$ and Epic $\AA$, appeared in the US market in 1985. Their success in the control of soil-dwelling phytopathogenic microorganisms has laid the foundation for exploring the application of Bacillus-based biopreparations to commercially important crops (Dardanelli et al., 2010; Khabbaz et al., 2015). In the study, Bacillus sp., which was isolated from Western Ghat soil was found to have remarkable antagonistic activity against Pythium myriotylum. 
The broad antifungal activity of Bacillus sp., against the selected pathogen was agriculturally important as these pathogens infect plants of great economic importance. Pythium species are best known for causing damping-off and seed rot disease that often occurs just after planting as young seedlings emerge. Pythium also causes root rots on newly emerged or more mature plants and can also cause soft rots of fleshy fruit. Damping-off disease affects seedlings worldwide. Often, young seedlings are completely destroyed by this pathogen with significant yield reduction. Older plants once emerged might not be significantly affected by Pythium, but do show symptoms of root rot. The ethyl acetate extract prepared from culture supernatant of Bacillus sp. was shown to retain the activity against Pythium myriotylum which confirmed the extracellular production of antifungal metabolites by the selected organism. From previous studies, Bacillus species has been reported to have the potential of producing wide array of antibiotics in strain specific manner (Shu-Mei 2012). In a study by Rao (Rao et al., 2013) Bacillus strains EU07, QST713 and FZB24, were investigated for their inhibitory effect on $\mathrm{Fu}$ sarium by production of lytic enzymes, cellulases, proteases, 1,4- $\beta$-glucanase and hydrolases. There are reports on the isolation and characterization of Bacillus sp. WG4 that protects alfalfa from seedling disease caused by Pytophthora megasperma (Handelsman et al., 1990). Bipolaris stem rot caused by $B$. cactivora was shown to be controlled by antifungal properties of Bacillus amyloliquefaciens species (Bae et al., 2013). In recent study a novel bacterium BH072 Bacillus amyloliquefaciens isolated from honey has showed strong antifungal activity against a lot of molds (Zhao et al., 2013). All these support the result of the current study. The additional impressive features with Bacillus sp. WG4 isolated in the current study are the plant growth promoting properties.
Rhizosphere Bacillus subtilis was reported to cause structural deformities in pathogenic fungi under in vitro culture conditions due to the production of diffusible and volatile antifungal compounds (Chakraborty et al., 2009). In current study, in vitro challenges of phytopathogenic fungi with the selected bacterium demonstrated efficient growth-inhibiting alterations in the morphology and structure of P. myriotylum by extracellular metabolites of Bacillus sp. WG4. Ultrastructural studies of the hyphae revealed the changes in the width and regeneration of its cell walls, hyphal constrictions in the region of the transversal septum and the induction of secondary branching in the fungal cell. The periodical swelling, torsion and formation of bulbs in hyphae from P. myriotylum have been previously reported to be linked to the action of antifungal metabolites (Ongena et al., 2004). The results also showed inhibition of conidial germination of $P y$ thium myriotylum and is important as inhibition of the pathogen at various stages can have efficient property to control the pathogen (Walker et al., 1998).

Synergistic effect of two antagonists combined into a single treatment can have more efficient biocontrol property (Khabbaz and Abbasi 2014). A microbial biological control agent may express contact inhibition against pathogens during their antagonistic activity by weakening or destroying the pathogen or by parasitizing it directly by producing antimicrobial compounds to compete for space and nutrients and by producing enzymes that attack the cell components of the pathogens. In this study, antagonistic effect expressed by the Trichoderma spp. in dual culture method might be due to one or combination of all the above mechanisms. Recent works suggest that the combination of several PGPRs could be more effective than individual strains as a horticultural product (Domenech et al., 2006). So the synergistic effect observed in this study can have promising applications. 
The antifungal activity of the bioactive fractions collected was checked, and was subjected to GC MS analysis. The MS of bioactive crude extract revealed a peak at a retention time of 30.358 min showing $98 \%$ similarity with pyrrolo [1,2- a] pyrazine-1,4dione, hexahydro-3-(phenylmethyl) with a molecular weight of 244.2. This novel pyrrolopyrazine alkaloid occurs in many plant-microbe relationships. These compounds have been isolated from the endophytes Epichloe species and the Neotyphodium sp. of grasses in cold regions and can protect plants against worms and phytopathogens (Faeth 2002; Leuchtmann and Schardl 2005; Malinowski et al., 2005; Zhang et al., 2012). This fungal metabolite consists of a lipophilic pyrrolopyrazine heterocyclic ring structure with a hydrophilic guanidinium side chain. It is related to other diketopiperazine-mycotoxins, such as aspergillic acid, and related pyrazine derivatives are produced by the Aspergillus and Candida species (Zhang et al., 2012).

Because of the broad biocontrol properties of Bacillus sp. WG4 isolated in the study, it was selected for studying its in vivo role to control rhizome rot in ginger. Rhizome rot is caused mainly by various species of Pythium. No feasible and ecofriendly method is available to protect the ginger plant from rhizome rot disease. Rhizospheric microorganisms capable of producing antimicrobial compounds could be a useful tool to prevent the disease. The in vivo antifungal activity of Bacillus sp. was analysed by pre-inoculation of this strain with ginger rhizome. Here the presence of Bacillus sp.WG4 was found to provide effective protection to ginger rhizome upon inoculation with Pythium myriotylum. This open up novel approaches to exploit rhizospheric microorganisms for biocontrol applications.

\section{Acknowledgements}

This study was supported by Department of Science and Technology, Government of India under DSTPURSE, KSCSTE- SARD and KSCSTE- SRS Program. The authors also acknowledge Department of Applied Chemistry, CUSAT, Cochin, Kerala, India for GC-MS analysis facility.

\section{Reference}

Ahmad, F., Ahmad, I., Khan, M.S. 2008. Screening of free-living rhizospheric bacteria for their multiple plant growth promoting activities. Microbiological Research. 163. 173-181.

Bae, S., Kim, S.G., Kim, Y.H. 2013. Biocontrol Characteristics of Bacillus Species in Suppressing Stem Rot of Grafted Cactus Caused by Bipolaris cactivora. The Plant Pathology Journal. 29, 42-51.

Chakraborty, U., Chakraborty, B.N., Basnet, M., Chakraborty, A.P. 2009. Evaluation of Ochrobactrum anthropi TRS-2 and its talc based formulation for enhancement of growth of tea plants and management of brown root rot disease. Journal of Applied Microbiology. 107. 625-634.

Chaurasia, B., Pandey, A., Palni, L.M.S.,Trivedi, P., Kumar ,B., Colvin, N. 2005. Diffusible and volatile compounds produced by an antagonistic $B a$ cillus subtilis strain cause structural deformations in pathogenic fungi in vitro. Microbiological Research. 160, 75-81.

Chen, H., Wang, L., Su, C.X., Gong, G.H., Wang, P.,Yu, Z.L. 2008. Isolation and characterization of lipopeptide antibiotics produced by Bacillus subtilis. Letters in Applied Microbiology. 47, 180-186. 
Chun, J., Goodfellow, M.A. 1995. Phylogenetic Analysis of the Genus Nocardia with 16S rRNA Gene Sequences. International Journal of Systematic Bacteriology. 45, 240-245.

Dardanelli, M.S., Carletti, S.M., Paulucci, N.S., Medeot, D.B., Cáceres, E.R., Vita, F.A. 2010. Benefits of Plant Growth-Promoting Rhizobacteria and Rhizobia in Agriculture. 18. 1-20.

Domenech, J., Reddy, M.S., Kloepper, J.W., Ramos, B., Gutierrez-Mañero, J. 2006. Combined Application of the Biological Product LS213 with Bacillus, Pseudomonas or Chryseobacterium for Growth Promotion and Biological Control of Soil-Borne Diseases in Pepper and Tomato. Biocontrol. 51, 245-258.

Earl, A.M., Losick, R., Kolter, R. 2008. Ecology and genomics of Bacillus subtilis. Trends in Microbiology. 16, 269-275.

Faeth, S.H. 2002. Fungal Endophytes: Common Host Plant Symbionts but Uncommon Mutualists. Integrative and Comparative Biology. 42, 360-368.

Furlaneto, M.C., Andrade, C.G.T.J., Aragão, P.H.A., França, E.J.G., Moralez, A.T.P., Ferreira L.C.S. 2012. Scanning electron microscopy as a tool for the analysis of colony architecture produced by phenotypic switching of a human pathogenic yeast Candida tropicalis. Journal of Physics: Conference Series. 371, 012022.

Handelsman, J., Raffel, S., Mester, E.H., Wunderlich, L., Grau, C.R. 1990. Biological Control of Damping-Off of Alfalfa Seedlings with Bacillus cereus UW85. Applied and environmental microbiology. 56, 713-8.

Jimtha, J.C., Smitha, P.V., Anisha, C., Deepthi, T., Meekha, G., Radhakrishnan, E.K. 2014. Isolation of endophytic bacteria from embryogenic suspension culture of banana and assessment of their plant growth promoting properties. Plant Cell, Tissue and Organ Culture (PCTOC) 118, 57-66.
Katz, E., Demain, A.L. 1977. The peptide antibiotics of Bacillus: chemistry, biogenesis, and possible functions. Bacteriological reviews. 41, 449-74.

Khabbaz, S.E., Abbasi, P.A. 2014. Isolation, characterization, and formulation of antagonistic bacteria for the management of seedlings damping-off and root rot disease of cucumber. Canadian Journal of Microbiology. 60, 25-33.

Khabbaz, S.E., Zhang, L., Cáceres, L.A., Sumarah, M., Wang, A., Abbasi, P.A. 2015. Characterisation of antagonistic Bacillus and Pseudomonas strains for biocontrol potential and suppression of damping-off and root rot diseases. Annals of Applied Biology. 166, 456-471.

Lamsal, K., Kim, S.W., Kim, Y.S., Lee, Y.S. 2012. Application of Rhizobacteria for Plant Growth Promotion Effect and Biocontrol of Anthracnose Caused byColletotrichum acutatumon Pepper. Mycobiology. 40, 244.

Lee, Y.S., Kim, K.Y. 2016. Antagonistic Potential of Bacillus pumilus L1 Against Root-Knot Nematode,Meloidogyne arenaria. Journal of Phytopathology. 164, 29-39.

Leuchtmann, A., Schardl, C. 2005. The Epichloë Endophytes of Grasses and the Symbiotic Continuum. 0554, 475-503.

Malinowski, D.P., Belesky, D.P, Lewis, G.C. 2005. Abiotic Stresses in Endophytic Grasses. 187-199.

Malviya, M.K., Sharma, A., Pandey, A., Rinu, K., Sati, P., Palni, L.M.S. 2012. Bacillus subtilis NRRL B-30408: A potential inoculant for crops grown under rainfed conditions in the mountains. Journal of soil science and plant nutrition. 12, 811-824.

Mora, Y., Diaz, R., Vargas-Lagunas, C., Peralta, H., Guerrero, G., Aguilar, A. 2014. Nitrogen-Fixing Rhizobial Strains Isolated from Common Bean Seeds: Phylogeny, Physiology, and Genome Analysis. Applied and environmental microbiology. 80, 5644-5654. 
Ongena, M., Duby, F., Jourdan, E., Beaudry, T., Jadin, V., Dommes, J. 2004. Bacillus subtilis M4 decreases plant susceptibility towards fungal pathogens by increasing host resistance associated with differential gene expression. Applied Microbiology and Biotechnology. 67, 692-698.

Rao, C.V., Baysal, Ö., Lai. D., Xu, H-H., Siragusa, M., Çalışkan, M.A. 2013. Proteomic Approach Provides New Insights into the Control of SoilBorne Plant Pathogens by Bacillus Species. PLoS ONE. 8, e53182.

Ruano-Rosa, D., Cazorla, F.M., Bonilla, N., MartínPérez, R., De Vicente, A., López-Herrera, C.J. 2013. Biological control of avocado white root rot with combined applications of Trichoderma spp. and rhizobacteria. European Journal of Plant Pathology. 138, 751-762.

Schaeffer P. 1969. Sporulation and the production of antibiotics, exoenzymes, and exotonins. Bacteriological reviews. 33, 48-71.

Seidl, V., Huemer, B., Seiboth, B., Kubicek, C.P.A. 2005. Complete survey of Trichoderma chitinases reveals three distinct subgroups of family 18 chitinases. FEBS Journal. 272, 5923-5939.

Shu-Mei, Z. 2012. Isolation and characterization of antifungal lipopeptides produced by endophytic Bacillus amyloliquefaciens TF28. African Journal of Microbiology Research. 6.

Soylu, S., Soylu, E.M., Kurt, S,K., Ekici, O. 2005. Antagonistic Potentials of Rhizosphere-associated Bacterial Isolates Against Soil-borne Diseases of Tomato and Pepper Caused by Sclerotinia sclerotiorum and Rhizoctonia solani. Pakistan Journal of Biological Sciences. 8, 43-48.
Tamura, K., Peterson, D., Peterson, N., Stecher, G., Nei, M., Kumar, S. 2011. MEGA5: molecular evolutionary genetics analysis using maximum likelihood, evolutionary distance, and maximum parsimony methods. Molecular biology and evolution. 28, 2731-9.

Walker., Powell., Seddon. 1998. Bacillus isolates from the spermosphere of peas and dwarf French beans with antifungal activity against Botrytis cinerea and Pythium species. Journal of Applied Microbiology. 84, 791-801.

Zaccardelli, M., De Nicola, F., Villecco, D., Scotti, R. 2013. The development and suppressive activity of soil microbial communities under compost amendment. Journal of soil science and plant nutrition. 13, 730-742.

Zhang, X., Li, C., Nan, Z. 2012. Effects of cadmium stress on seed germination and seedling growth of Elymus dahuricus infected with the Neotyphodium endophyte. Science China Life Sciences. 55, 793-799.

Zhang, Z., Schwartz, S., Wagner, L., Miller, W.A. 2000. Greedy algorithm for aligning DNA sequences. Journal of computational biology : a journal of computational molecular cell biology. 7, 203-14.

Zhao, X., Zhou, Z-J., Han, Y., Wang, Z-Z., Fan, J., Xiao, H-Z. 2013. Isolation and identification of antifungal peptides from Bacillus BH072, a novel bacterium isolated from honey. Microbiological Research. 168, 598-606. 